\title{
An Analysis of the Relationship Between Access to Loans and District Poverty Rate in Malawi
}

\author{
S. H. Dunga \\ North West University (Vaal Triangle Campus), \\ P.O Box 1174, Vanderbijlpark, South Africa \\ Email: Steve.dunga@nwu.ac.za
}

Doi:10.5901/mjss.2014.v5n13p134

\begin{abstract}
Access to credit is one of the important channels that developing countries can employ in the effort to reduce poverty. Literature shows that the countries that have expanded the accessibility of credit and loans to vulnerable households have also registered positive results in poverty reduction. This study investigated the relationship between district poverty rate and access to loans and credit in Malawi. The apriori expectation was that with an increased access to loans for agricultural households, there will be a resultant reduction in poverty. Using panel data from Integrated Household Survey (IHS1) 2 and 3 in a random effects regression model, the results show that there is a relationship between access to loans and poverty reduction with the increase in the former leading to the reduction of the later. Also literacy rate and access to electricity were used as control variables and were significant factors in the results
\end{abstract}

Keywords: panel data, IHS, Loan, Accessibility, Poverty reduction

\section{Introduction}

The number of poor people in the world remains high as 2015 draws closer. The sub Saharan Africa has the most poor people in percentage terms. Poverty in Malawi like in most Sub Saharan countries remains high amid efforts by government and partner organisation in poverty reduction. The latest national wide figures released in September 2012 under the Integrated Household Survey three, reported poverty to be at $50.7 \%$ at national level (NSO: 2012:206) The bigger share of the poor people is found in the rural areas of the country with the poverty rate at $56.6 \%$ in the rural areas and $17.3 \%$ in the urban areas(NSO:2012:206). It is therefore pertinent and of great importance to continue researching into strategies that would help deal with the poverty situation in the region and the country in particular. This paper looks at the relationship between access to loans and poverty reduction at district level in Malawi. Access to credit is one of the important channels that developing countries can employ in the effort to reduce poverty. Literature shows that the countries that have expanded the accessibility of credit and loans to vulnerable households have also registered positive results in poverty reduction.

\section{Literature Review on the Relationship Between Access to Loans and Poverty Reduction}

The literature is ubiquitous with strategies to reduce poverty in the developing countries where incidences of poverty are high. And these strategies appear to come from many angles. Access to credit is one of the important channels that developing countries can employ in the effort to reduce poverty. The fact that unemployment is very high in most of these developing countries call for other strategies that do not rely on getting employed only. One area that has a lot of potential is the small and medium enterprises. Literature shows that the countries that have expanded the accessibility of credit and loans to vulnerable households have also registered positive results in poverty reduction. Most households in developing countries like Malawi are agricultural with no formal employment and it make difficult for them to access loans and credits from the formal financial sector. With all the efforts that have been put over the years to reduce poverty, there still remain a lot of people that are stuck in poverty. As part of the poverty alleviation strategy, governments in other developing countries like India (Shastri, 2009) Malawi (Diagne \& Zeller, 2001) Ethiopia (Pitamber, 2003) have put in place measures that help poor households to access loans mainly for small enterprise and agricultural inputs. According to Shastri (2009) on arguing for India pointed out that the dynamic growth of the microfinance industry has been promoted not only by market forces but to a greater extent also by conscious actions of national governments, Non-Governmental

\footnotetext{
1 Integrated household Survey is a huge comprehensive country wide data collection exercise carried out by the National Statistics Office of Malawi. So far there have been three rounds known as IHS1 IHS 2 and IHS 3
} 
Organizations (NGOs), and the donors who consider microfinance and access to credit by poor households as an effective tool for dealing with poverty. The relationship between access to credit and poverty reduction is therefore a welldocumented one in the literature. Other studies that have shown a positive impact of access to credit on poverty reduction include (Bhandari, 2009; Quach, Mullineux, \& Murinde, 2005; WorldBank, 2007; Pitamber, 2003) among others World Bank among the other international organisation has been in the forefront promoting access to loans and credits. In the World Bank report it is argued that financial sector development is consistent with pro poor growth (WorldBank, 2007, p. 99). A study by Shastri (2009) in India looked at the dynamic growth of the micro finance industry and how in recent years there has been a lot of support towards the increasing of loan and credit accessibility of poor households. Also in India, Bhandari (2009) he found that the reduction in poverty is not necessarily associated with the formal banking sector. Using the number of account created in the formal sector as a measure of access to loans he found that there was no significant relationship with poverty reduction. A study in Vietnam by Quach et al. (2005) found that household credit contributed positively to economic welfare of the households. The significant contribution was found on per capita expenditure, per capita food and non-food expenditure (Quach, Mullineux, \& Murinde, 2005, p. 1) they further argued that the positive impact found in Vietnam was on both poor and non-poor household

\section{Methodology}

The study uses data from Intergrated Household Survey 2 and 3 collected by the National Statistics Office of Malawi. The survey collected data from households on a number of enterprise related aspects. It also collected data on Households access to loans and what the loan was used for. from the literature, as agued by Shastri and Pitamber, access to credit and loans have a positive impact on poverty reduction. This Study uses district poverty rate for the two IHS rounds as a dependent variable and a number of loan accessibility indicators as dependent variables as specified in section 3.2 below. the model uses panel data and was run in STATA using random effects GLS regression.

\subsection{Model Specification}

The study used random effects model as opposed to fixed effects model.This is because there are a number of weaknesses with the Fixed Effects Model (FEM). Some of the weaknesses in the FEM is that degrees of freedom are lost by including too many dummy variables. an easy way is to account for the differences in the intercepts by putting them in the error term. The random effects model takes that into account. It has a composite of the error term from the individual districts and the one from the model. The intercept used therefore is the mean of all the district intercepts, and the individual errors are a representation of the diversion of the district intercept from the mean intercept. So the REM also known as the ECM is of the following form;

$D P R_{i t}=\beta_{1 t}+\beta_{2} X_{2 i t}+\beta_{3} X_{3 i t}+u_{i t}$

Instead of treating $\beta_{11}$ as fixed, it is assumed that it is a random variable with a mean value of $\beta 1$ without the subscript i. And the intercept value for an individual district can be expressed as;

$\beta_{1 i}=\beta_{1}+\varepsilon_{i} \mathrm{i}=1,2 \ldots \mathrm{N}$

Where $\varepsilon_{i}$ is a random error term with a mean value of zero and variance of $\sigma_{\varepsilon}^{2}$. so equation (1) then becomes;

$D P R_{i t}=\beta_{1}+\beta_{2} X_{2 i t}+\beta_{3} X_{3 i t}+\varepsilon_{i}+u_{i t}$

$\varepsilon_{i}+u_{i t}=w_{i t}$ There fore

$D P R_{i t}=\beta_{1}+\beta_{2} X_{2 i t}+\beta_{3} X_{3 i t}+w_{i t}$

Where, $w_{\text {it }}$ is the composite error term. The composite error term $w_{i t}$ consists of two components, $\varepsilon_{i}$, which is the cross-section, or individual district -specific, error component, and $u_{i t}$, which is the combined time series and cross-section error component. The model estimated used the district poverty rate as a dependent variable and a number of loan aspects as independent variables is as follows;

$D P R_{i t}=\beta_{1 i t}+\beta_{2 i t} A t E_{i t}+\beta_{3 i t} L f A_{i t}+\beta_{4 i t} L t B L_{i t}+\beta_{5 i t} L f B s_{i t}+\beta_{6 i t} L f T I_{i t}+\beta_{7 i t} P r L_{i t}+\omega_{i t}$

Where DPR is the District Poverty Rate, $\beta_{1 \mathrm{it}}$ is the random effects intercept term, $\beta_{2 \mathrm{it} . . .7 \mathrm{it}}$ are the coefficients for the independent variables. AtE is access to electricity, LfA is loan for agricultural inputs, LtBL is percentage of people with a Loan to buy land LfBs is the percentage of people with a loan for business start-up LfTI is the percentage of people with a loan for tobacco inputs, Prl is the proportion of people in the district receiving a loan and $\omega_{i t}$ is the random effects composite error term.

To conform the selection of random effects a Breusch Pagan test can be conducted. the random effects model was opted for as opposed to the fixed effects model in this analysis of access to loans and poverty reduction based on the Breusch -Pagan test. 
Table 1: Breusch and Pagan lagrangian Multiplier test for random Effects

\begin{tabular}{|c|c|c|}
\hline \multicolumn{3}{|c|}{ Poverty rate head count (district) } \\
\hline \multicolumn{3}{|c|}{ Estimated results } \\
\hline & variance & Sd = square root (var) \\
\hline Poverty rate & 286.9433 & 16.9394 \\
\hline $\mathrm{e}$ & 88.52743 & 9.408901 \\
\hline $\mathrm{u}$ & 187.8661 & 13.70642 \\
\hline Test; $\operatorname{Var}(\mathrm{u})=0$, Chi-bar 2 (01) $=11.92, \mathrm{p}$-value $=0.0003$ \\
\hline
\end{tabular}

Calculatins from NSO data (IHS2 and IHS 3)

The BP test for the access to loans model had a chi squared test statistic of 11.92 and a p-value of 0.0003 which lead to the rejection of the null hypothesis that variance is equal to 0 . The null hypothesis that variance is equal to zero means that there are no random effects and hence not appropriate to use random effects. The results of the test for the model 5 rejects this null hypothesis. This entails that the best model for this panel data set is the random effect model as specified above.

\subsection{Results}

A number of variables that were used to measure loan accessibility have been used in the model. This helps to capture the variable of interest from all the possible angles. The section below presents the descriptive statistics of the independent variables and also the results from the random regression model as specified in equation (5) above

\subsection{Descriptive statistics}

Table 2 below reports the descriptive statistics of the variables in model (5) above. Access to electricity was included as a control variable due to its significant relationship with poverty status. Studies like that by Tchereni (2013) has found a significant positive correlation between access to electricity and being non poor. the fact that most people represented in the sample are based in the rural areas, having access to electricity meant that they also would be able to be engaged in business common in the rural areas like battery charging, phone charging, and selling of cold drinks and hence would be reason enough for these households to seek for a loan. The other variables are directly linked to the objective of the study on the relationship between access to loan and poverty rate at district level. All the variables used are district percentages, for example proportion of people that received a loan shows that on average $10.37 \%$ of people across the districts in Malawi received a loan. The highest percentage that received a loan was 27.3 for Nkhotakota district and the lowest was $1.1 \%$ for Mangochi, giving a standard deviation of 5.95 .

Table 2: Descriptive statistics of the variables

\begin{tabular}{l|c|c|c|c|c|}
\multicolumn{1}{c}{ Variable } & Obs. & mean & Std. dev. & Min & Max \\
\hline Literacy rate & 62 & 66.94 & 14.02 & 34.1 & 93.1 \\
\hline Access to electricity & 62 & 7.01 & 11.117 & 0 & 44.4 \\
\cline { 2 - 7 } Loan for agro inputs & 62 & 23.01 & 16.31 & 0 & 65.7 \\
\hline Proportion that received a loan & 62 & 10.37 & 5.95 & 1.1 & 27.3 \\
\cline { 2 - 7 } Loan to buy land & 62 & 1.04 & 2.39 & 0 & 10.3 \\
\hline Loan for business start up & 62 & 40.0 & 18.90 & 6.6 & 78.3 \\
\cline { 2 - 6 } Loan for tobacco inputs & 62 & 11.0 & 17.95 & 0 & 67.1 \\
\hline
\end{tabular}

Calculated from NSO data (IHS 1, IHS 2 and IHS 3)

The expectation of a positive correlation between access to loans and poverty reduction is also reflected in these two extreme districts, the head count poverty rate for Nkhotakota is 48 below the national at $54 \%$ and that of Mangochi is $73 \%$ far higher than the national average. The highest percentage of the types of loans received was $78 \%$ for business start-up and it was registered by Mulanje. This however was the percentage of the received loans, and for Mulanje district, the proportion of people receiving loans was just 7.8 , hence $78 \%$ of these $7.8 \%$ were for business start-up. Table 1 above has the details of the descriptives of all the other variables included in the model.

\subsection{Results of the Random effects model}


The random effects regression model presented in Equation (5) was run in Stata and the results are as reported in table 3 below;

Table 3: Results of the random effects GLS regression for equation 1

\begin{tabular}{|c|c|c|c|c|}
\hline DistrictPoverty rate & Coef. & Std. Err. & $\mathbf{z}$ & $P>|z|$ \\
\hline Access to electricity & -1.0355 & .1385742 & -7.47 & $0.0000^{\star \star \star}$ \\
\hline \multirow{2}{*}{$\begin{array}{l}\text { Loan for agric inputs } \\
\text { Propotion receiving a loan }\end{array}$} & .0342 & .1117921 & 0.31 & 0.759 \\
\hline & -.5032177 & .2634521 & -1.91 & $0.056^{*}$ \\
\hline \multirow{2}{*}{$\begin{array}{l}\text { Loan to buy land } \\
\text { Loan for business start up }\end{array}$} & -1.096321 & .5833007 & -1.88 & $0.060^{*}$ \\
\hline & .2229081 & .117896 & 1.89 & $0.059^{*}$ \\
\hline \multirow{2}{*}{$\begin{array}{l}\text { Loan for tobacco inputs } \\
\text { constant }\end{array}$} & .1118941 & .1023866 & 1.09 & 0.274 \\
\hline & 54.75106 & 8.676472 & 6.31 & $0.0000^{\star \star \star}$ \\
\hline
\end{tabular}

Table 2 above presents results of the random effects regression from equation 1 above. The district poverty rate from IHS 2 and IHS 3 were used as dependent variable. The Chi 2 test for the model has a p value of 0.000 shows that the model is a good fit even at $1 \%$ level of significance. Section 3.4 below discusses the results in detail.

\subsection{Discuassion of the results}

The results in table 1 above shows that Access to electricit proportion of people receiving a loan, getting a loan to buy land and getting a loan for business start-up are significant factors explaing the district poverty rate in Malawi. For example having access to electricity which was used as a control variable, has the expected negative sign which means the more people have access to electricity, the lower the district poverty rate. a unit chage in the percentage of those in the district with access to electricity reduces the incidence of poverty in the dictrict by 1.0355 percentage points. this is almost a one to one responce. this result is similar ro the claim by Dollar and Kraay (2000) where they found that growth reduced poverty at a one to one effect rate.

The number of people accessing loans also produced a negative sign as expcted, meaning, as more and more people access loans for what ever reason, the district poverty rate declines. the regression result shows the a unit change in the percentage of people accessing loans leads to a 0.5 reduction in the district poverty rate. This is the same result found by ...... and also ... where they found that aincreasing access to creadit and loans to the poor households reduces the incidences of poverty in those countries. related to access to loan are the loan for business start-up and loand to buy land which were also significant at $10 \%$. a unit increase in the percentage of people accessing a loan to buy land has a 1.096 reduction effect on the district poverty rate. This is an indacation that buying land etails access to land which according to a study by Chirwa et al. (2008) has a direct bearing on poverty. People with access to land in Chirwa's study were found to have lower probability of being poor as compared to landless people who had a higher probability of being poor. Loans that were taken for garicultural unputs like were not significant even the loans taken particulally for tobacco input. this could be because tobacco is grown only in a few district in the country.

\section{Conclusion}

The importance of loans in the poverty reduction efforts have been confirmed in the data analysis. The regression results show a negative relationship between district poverty rate and the proportion of people that obtained a loan. This was in agreement with theory and apriori expectation that the more people have access to loans the lower the incidence of poverty. It was also reported under the descriptives that most people obtained their loans for business start-ups. This implies a positive correlation between loans and business being started. It can be concluded from this finding therefore that, if governments are interested in reducing poverty incidences in the districts, there is need to provide more opportunities for loan accessibility. This would in the process reduce the burden of job creation on the part of government as the people are able to start-up businesses. 


\section{References}

Agrawal, P. (2008). Economic growth and Poverty Reduction: Evidence from Kazakhsatan. Asian Development Review, 24(2), $90-115$.

Aigbokhan, B. E. (2008). Growth, Inequality and Poverty in Nigeria. Addis Ababa, Ethiopia: United Nations Economic Commission for Africa (UNECA).

Albright, J. J. (2007). Estimating Multilevel Models using SPSS, Stata, and SAS.

Amann, E., Aslanidis, N., Nixson, F., \& Walters, B. (2002). Economic growth and poverty alleviation: A reconsideration of Dollar and Kraay. Manchestr: School of Economic Studies.

Bhandari, M. K. (2009). Access to banking services and poverty reduction: a state wise assessment in India. IZA discussion papers, No. 4132. http://nbnnbnresolving.de/urn:nbn:de:101:1-20090513309.

Datt, G., Simler, K., Mukherjee, S., \& Dava, G. (2002). Determinants of poverty in Mozambique: 1996-97 food consumption and nutrition division discussion paper No 78. International Food Policy Research institute. Washington DC.

De Janvry, A., \& Sadoulet, E. (1995). Poverty alleviation, income distribution and growth during adjustiment. In N. Lustig, Coping with Austerity: poverty and Inequality in Latin America. Washington, DC: brookings Institution.

De Janvry, A., \& Sadoulet, E. (2000). Growth, poverty and inequality in latin Amarica: A causal analysis, 1970-94. review of Income and Wealth, 46(3), 267-287.

NSO, (2012) Integrated Household Survey 3. Government press, Zomba Malawi

Morduch, J. (2002). Analysis of the Effects of Microfinance on Poverty Reduction. NYU Wagner Working Paper No. 1014.

OPHI (2013). Malawi Country Briefing", Multidimensional Poverty Index Data Bank. Oxford: OPHI, University of Oxford. Available at: www.ophi.org.uk/multidimensional-poverty-index/mpi-country-briefings

Patrick, H. (2004). Measuring Microfinance Access: Building on ExistingCross-Country Data". Workshop on the Access of Poor and Low Income People to.

Pitamber, S. (2003). Factors Impeding the Poverty Reduction Capacity of Micro-credit: Some Field Observations from Malawi and Ethiopia. Abidjan: The African Development Bank.

Quach, M. H., Mullineux, A. W., \& Murinde, V. (2005). Access To Credit And Household Poverty Reduction In Rural Vietnam: A CrossSectional Study. The Birmingham Business school. Birmingham: University of Birmingham.

WorldBank. (2007). Finance For All? Policies And Pitfalls In Expanding Access, (Chapter 3)Household Access to Finance:Poverty Alleviation and Risk Mitigation. (pp. 100-137). siteresources.worldbank.org/intfinforall/Resources/.../ffa_book. 